Uşak Üniversitesi Sosyal Bilimler Dergisi

$2014,7 / 3$

\title{
Amerika Birleşik Devletleri Michigan Eyaletinde İlköğretim Birinci Sınıflarında Kullanılan İlk Okuma Yazma Öğretim Programlarının İncelenmesi*
}

Yalçın BAY*

\section{Özet}

Bu çalışmayla, Amerika Birleşik Devletlerinin, Michigan eyaletinde İlköğretim birinci sinıflarında kullanılan okuma yazma öğretim programlarının tanıtılması amaçlanmıştır. Araştırmanın yürütülmesinde nitel araştırma yöntemlerinden, doküman inceleme ve kaynak tarama tekniği kullanılmıştır. Araştırmada 2011 - 2012 eğitim öğretim yılında, Amerika Birleşik Devletleri, Michigan eyaletinde kullanılan okuma yazma öğretim programları oluşturmaktadır.

Araştırma kapsamında birinci sınıflara okuma yazma öğretim sürecinde kullanılan programlar incelenmiştir. Programlarda yer alan genel amaçlar, beceriler, hedefler, davranışlar/kazanımlar, öğrenme öğretme durumu/etkinlikleri belirlenmiştir. Programlarda hangi ölçme ve değerlendirme teknikleri kullanıldığı belirlenmiştir. Öğretmenlerin okuma yazma öğretiminde programlardan istedikleri programı seçebildikleri tespit edilmiştir. $\mathrm{Bu}$ programlar içerisinden her hangi bir programın uygulanmasına yönelik bir zorunluluk bulunmadığı tespit edilmiştir. Örnek Programlar incelendiğinde okuma yazma öğretim sürecinin okul öncesi eğitimle birlikte başladığı anlaşılmıştır. Örnek Programlarda ön görülen ilk okuma yazma öğrenme sürecinin yaklaşık 3 yıl gibi uzun bir süreci kapsadığ1 belirlenmiş̧tir. Okuma yazma öğretimine yönelik olarak, okul öncesi eğitimde de yaklaşık 60 civarında amaç kazanım yer almaktadır. Okul öncesi öğretim programında yer alan amaç kazanımlar, birinci sınıfta yapılması gereken ilk okuma yazmaya hazırlık çalışma sürecini

* Bu çalışma, 24-26 Mayıs 2012 tarihlerinde Recep Tayyip Erdoğan Üniversitesi Eğitim Fakültesi tarafından düzenlenen "11. Ulusal Sınıf Öğretmenliği Eğitimi Sempozyumu"nda sunulan sözlü bildiriden geliştirilerek hazırlanmıştır.

${ }_{* *}^{*}$ Yrd. Doç. Dr., Eskişehir Osmangazi Üniversitesi, İlköğretim Bölümü, Okul Öncesi Eğitimi Anabilim Dalı, yalcinbay73@gmail.com 
kısaltmaktadır. Bu nedenle birinci sinıflarda ilk okuma yazmaya hazırlık sürecinin daha kısa olduğu tespit edilmiştir.

Araştırma sonucunda öğretmenlerin okuma yazma öğretiminde istedikleri yöntemi seçebilecekleri tespit edilmiştir. Bu çalışmanın, araştırmacıların ve sınıf öğretmenlerinin dünyadaki farklı uygulamalar ve okuma yazma öğretim programları konusunda bilgilenmelerine katkı sunacağına inanılmaktadır.

Anahtar Kelimeler: Okuma Yazma Öğretimi, Program Geliştirme, Türkçe Öğretimi.

\section{Samples of Early Reading and Writing Curriculum Used in First Grade of Elementary School in State of Michigan United States of America}

\section{Abstract}

With this research, we aimed to introduce shortly the sample teaching reading and writing programs used in the first grades of primary schools in the State of Michigan, United States of America. We used document review and literature review techniques among qualitative research techniques in conduction of the research. The universe of research is consist of the reading and writing programs used in the State of Michigan in The United States of America in 2011-2012 educational year.

Within the scope of the research, the teaching programs used in the process of teaching reading and writing were examined. General purposes, skills, targets, behaviors/acquisitions, teaching and learning status/activities were determined. It was determined what measurement and evaluation techniques were used in the programs. It was determined that teachers could choose the program they wanted among the programs. It was determined that there is not obligation towards the conduction of any program among the sample programs. When the sample programs were examined, it was understood that the process of teaching reading and writing starts with preschool education. It was determined that the process of reading and writing anticipated in the sample programs cover a long time such as about three years. There are approximately 60 target acquisitions in preschool education towards teaching reading and writing. The target acquisitions in preschool teaching program shorten the process of preparation to early reading and writing. Thus, it was determined that the process of preparation for early reading and writing in first grades is shorter. 
We determined that teachers could choose the method they wanted in teaching reading and writing. This research is believed to contribute researchers and classroom teachers about different applications in the world and teaching reading and writing programs.

Key Words: Teaching Reading and Writing, Program Development, Teaching Turkish.

\section{Giriş}

Türkiye'de ilk okuma yazma öğretim programı gelişim süreci kısaca incelediğinde 1924, 1926, 1930, 1936, 1948, 1968, 1981 ve 2005 yıllarında olmak üzere toplam sekiz defa öğretim programlarında köklü değişikliklerin yapıldığı görülmektedir (Bay, 2006).

3 Mart 1924'te çıkarılan 430 sayılı Tevhid-i Tedrisat (öğretim birliği) Yasası ile tüm okullar Eğitim Bakanlığına bağlanmış ve medreseler kaldırılmıştır. Yapılan bu değişiklikle, tüm eğitim kurumlarında ilk okuma yazma öğretimi olarak harf yöntemi kullanılmaya başlanmıştır. 1924 ilkokul öğretim programında harf ve ses yöntemi benimsenmiş ve elifba öğretimi yapılmaktadır. Harflerin isimleri ile söylenişleri değil cümle ve kelime içindeki sesleriyle öğretilecektir. Böylece seslerin cümle içinde doğru kullanılışı öğretilmiş olacaktır. Harfler öğretilirken elifbadaki harf ve hece düzenine bağlı kalınmayacaktır, örneğin (Elif, be, te, se, he) şeklinde okutulmayacaktır. Elifba dersi yazı ile aynı zamanda okutulacak ve çocuklar her okudukları kelime ve cümleyi yazacaklar ve yazdıklarını okuyacaklar. Bir harfin yazı ve okuması tam anlamıyla öğretilmedikten sonar bir sonrakine geçilmeyecektir (MEB, 1924).

1926 İlkokul Programında ilk okuma yazma öğretiminde yöntem değişikliğine gidilmemiştir. Harf yöntemiyle ilk okuma yazma öğretimine devam edilmiştir. Milli Eğitim Sistemini düzenlemek amacıyla, 22 Mart 1926 tarihinde 789 sayılı Yasa ile Maarif Teşkilatı Kanunu Kabul edilmiştir. Bu kanunla bugünkü Talim ve Terbiye Kurulu, 22 Mart 1926 tarihinde kurulmuştur. Böylece yeni düzenlemelerin yanı sıra, sistemin bugünkü eğitim kademeleri belirlenmiş ve tüm eğitim kurumları Eğitim Bakanlığı'nın bünyesine alınmıştır (Akyüz, 1999). Yapılan kanuni değişiklerin ardından, 1 Kasım 1928 tarih ve 1353 sayılı Yasayla yapılan Harf İnkılabı Cumhuriyetin en köklü değişikliğidir. Harf inkılabı ile Arap Elifbasından vazgeçilerek, Latin Alfabesi kullanılmaya başlanmıştır. Latin alfabesi Türkçenin daha iyi ifade edilebilmesine imkân sağlayacak şekilde yeniden düzenlenmiş ve Latin harflerin kullanıldığı yeni Türk Alfabesi oluşturulmuştur (Ergün, 2005). Yeni Türk alfabesi: “a, b, c, ç, d, e, f, g, 乌̆ , h, i, l, j, k, l, m, n, o, ö, p, r, s, 
ş, t, u, ü, v, y, z". Geliştirilen bu program ve önerilen ilk okuma yöntemi 1930 yılına kadar 4 yıl süreyle kullanılmıştır (MEB, 1926).

Bir önceki programdaki hedefler aynen korunmuştur. Alfabe ve yazı öğretimiyle ilgili yeni önerilere yer verilmiştir. Bu programda ses ve kelime yöntemi birlikte kullanılmaya başlandığından dolayı yeni tedbirler alınmıştır. Harf öğretiminde belli bir sıra izlemek yerine basitten karmaşığa, kolaydan zora olmak üzere bir öğretim yaklaşımının benimsenmesi önerilmiştir. Harflerin öğretimine büyük harflerden başlanılması ve büyük harfler öğrenildikten sonra küçük harflerin öğretilmesi benimsenmiştir. Yazı öğretiminde dik temel harf veya eğik yazı kullanılması tamamen öğrencilerin tercihlerine bırakılmıştır. Geliştirilen bu program ve önerilen ilk okuma yöntemi 1936 yılına kadar 6 yıl süreyle kullanılmıştır (MEB, 1930).

1936 İlk Mektep Öğretim Programı ile 2005 İlköğretim (1-5. Sınıflar) Türkçe Ders Programı arasında önemli benzerlikler vardır. 1936 programı ses, harf ve kelime yöntemini birlikte kullanılmasını önermektedir. Bu programa göre harflerin hemen öğretiminden sonra bu harflerin kelime içerisinde kullanımı öğretilmeli, örnek kelimeler verilmeli ve bu kelimelerden oluşan düzenli cümleler oluşturulması önerilmektedir. 2005 ilköğretim Türkçe Dersi Programında ise Ses Temelli Cümle Yönteminin kullanılması benimsenmiştir. Burada ise önce en çok kullanılan seslerin öğretilmesi, ilk ses öğretiminden başlanılmak kaydıyla seslerin kelimenin başında, ortasında ve sonunda bulunma durumlarına göre örnek kelimeler öğretilmesi benimsenmiştir. Öğrenilen bu kelimelerden anlamlı cümlelerin oluşturulması önerilmiştir. 1936 programı ilk okuma yazma öğretimine harflerin öğretimiyle başlarken, 2005 programı ise seslerin öğretimiyle başlamaktadır. Ancak ilk okuma yazma öğretiminin aşamalarında çok önemli benzerlikler söz konusudur (MEB, 1936).

1948 yılında geliştirilen bu öğretim programıyla önerilen ilk okuma yazma öğretim yöntemi 1968 yılına kadar 20 yıl süreyle kullanılmıştır. Yeni yöntemin daha iyi uygulanabilmesine yönelik bir takım düzenlemeler yapılmıştır. İlk okuma yazma öğretimine basit cümleler ve kelimeler ile başlanılacaktır. Zamanla bu cümleler kelimelere, kelimeler hecelere, heceler ise harflere bölünecektir; bu çözümlemeler sonucunda elde edilen kelime, hece ve harflerden yeni cümle ve kelimeler oluşturulacaktır. Bu sırada Türk alfabesinde yer alan tüm harflerin metinlerde gereği kadar tekrarlanmasına dikkat edilecektir. Okuma yazma öğretimi faaliyeti daima beraber yürütülecek; çocuklar okumasını öğrendikleri cümle ve kelimeleri aynı 
zamanda yazacaklardır (MEB, 1948). İlk okuma yazma öğretiminde kitaptan başka faydalanılacak araç gereçler;

1. Okuyup yazılması öğrenilecek kelime ve cümleleri içeren büyük küçük fiş cümleleri.

2. Öğrenilen kelime ve cümlelerden meydana getirilmiş okuma parçaları; hikayeler, tekerlemeler, bilmeceler, manzumeler.

3. Öğrencilerin hazırlayacağı; çöp taneleri, taştahta, sınıf dergileri, alfabe kitabı ve diğer araçlar (Günçer, 1952).

1968 öğretim programında yapılan yeniliklerden biri ise; İlk okuma yazma öğrenmeye başlanırken programın çizdiği yazı esaslarına uygun olarak büyük küçük harfler birlikte öğretilmesidir. Harflerin şekillerine, yazılış yönlerine, satırda kapladıkları yerlere, büyük harflerin küçük harflerle ilişkilerine, bir birine oranlarına ihtiyaç duyuldukça dikkat çekilmelidir. Okuma yazmayı öğrenmede alıştırmanın önemli bir rolü vardır. Ancak bir şeyin sadece tekrar edilmesinin çokta fazla önemi yoktur. Sıkıcı cümle tekrarları yerine, öğrencilerin ilgilerini çeken cümleler kullanılmalıdır. $\mathrm{Bu}$ cümleler, tekerlemeler, fikralar ve ilgi çekici hikâyeler içerisinde kullandırılabilir. Öğretmen öğrettiği cümleleri tahtaya ve öğrencilerin defterlerine yazdırmalı ve cümlelerin yazılış şekillerine dikkat edilmelidir (MEB, 1968).

1981 öğretim programında daha önceki programlarda yer almayan ilk okuma yazma öğretimine hazırlık çalışmaları yer almıştır. Okula yeni gelen çocukların çoğunluğu, okuma yazmaya başlamak için gerekli fiziksel, duygusal, toplumsal olgunluğa henüz erişmemiş ve bazı ön becerilerden yoksun olabilirler. Bu durumdaki çocuklar için bir hazırlık dönemi gereklidir. Hazırlık döneminde öğrencilerin ihtiyaçlarına göre neler yapılması gerektiği önceden planlanmalıdır. Bu planlama çerçevesinde yapılacak olan ön hazırlık çalışmaları aşağıda sırlanmaktadır: Okuma yazma için gerekli araç gereçleri kullanabilme hazırlı̆̆ı: Öğrenciler okula ve sınıfa alıştırıldıktan sonra ellerine okuma yazma araç gereçleri verilmeli ve nasıl kullanılacağı öğretilmelidir. Yazmaya hazırlık: kalem ve defter tutmanın öğretilmesinden sonra, önce sayfa üzerinde serbest çizgiler çizmeleri, bir tür karalama yapmaları sağlanmalıdır. Daha sonrada ince kaslarının gelişimine katkı sağlayacak çizgi çalışmaları yapılmalıdır. Okumaya hazırlık: bu dönemde tekniğe uygun olarak hazırlanmış olan araç gereçlerle okumanın soldan sağa doğru olduğu kavratılır. Okumada soldan sağa doğru gözün kavrama alanına genişletmek, bir satır bitince alt satıra geçme alışkanlığ kazandırmak için çalışmalar yaptırılmalıdır. Böylece yazılanların bir anlatım yolu olduğu sezdirilmeye çalışılmalıdır (2098 Tebliğler Dergisi, 1981). Üzerinde okunması ve yazılması öğretilecek cümle ve kelimelerin yazılı 
olduğu büyük ve küçük fişler verilmelidir. Yazı tahtası ve harfler (Bu harfler; Kâğıt, plastik, mukavva, vb.) den kesilmiş harfler, kelimeler çözümlenmeli, harfler tanındıkça yeni kelimeler yapılmalıdır (MEB, 1981).

2005 yılında yapılan öğretim programında ilk okuma öğretiminde daha önce kullanılan cümle yönteminden vazgeçilmiş ve yerine Ses Temelli Cümle Yöntemi benimsenmiştir. Ses Temelli Cümle Yönteminde ilk okumayazma öğretimine seslerle başlanmaktadır. Anlamlı bütün oluşturacak birkaç ses verildikten sonra seslerden hecelere, kelimelere ve cümlelere ulaşılmaktadır. İlk okuma-yazma öğretimi, kısa sürede cümlelere ulaşılacak şekilde düzenlenmelidir. İlk okuma-yazma öğretimi boyunca okuma ve yazma birlikte sürdürülmektedir. Okunan her öğe yazılmakta; yazılanlar da okunmaktadır. Yazı öğretiminde, öğrencilerin gelişimine uygun olan bitişik eğik yazı harfleri kullanılmaktadır (MEB, 2005a, 2005b, 2005c, 2005d). Türkiye'de yapılan ilk okuma yazma öğretimine yönelik yapılan tüm öğretim programlarını geliştirme ve değiştirme çabalarının temel amacı öğrencilere daha etkili ve verimli bir eğitim verebilmektir. Bu araştırma, yapılan çalışmalara ışık tutması ve ilk okuma yazma alanında farklı ülkelerdeki çalışma örneklerini alana kazandırması açısından önemlidir.

Etkili okuma yazma öğretim programının hazırlanması temel bir ihtiyaçtır. Bu ihtiyaç okuryazar bir toplum oluşturma amacından kaynaklanmaktadır (Allington, 2001). Okuma yazmayı öğrenmek öğrencilerin başarıları üzerinde önemli bir etkiye sahiptir. Gelişen ve değişen bilim ve teknoloji çağında eğitim programları sürekli güncellenmektedir. Bilimsel ve teknolojik gelişmeler eğitimin hizmetine sunulmaktadır. Amerika Birleşik Devletlerinde de eğitim programlarının geliştirilmesi ve güncellenmesi konusunda sürekli araştırmalar yapılmaktadır (Jasinowski, Eisen ve Kleinert, 2005). Amerikan İşgücü ve Becerileri Yeni Komisyonu Raporunda, iyi bir iletişim becerisi olan, problem çözme becerisi gelişmiş ve analitik düşünme becerilerine sahip bireylerin yetiştirilmesine ihtiyaç olduğunu belirmiştir (National Center on Education and the Economy, 2007).

Yapılan araştırmalar ve raporlar doğrultusunda 2010 Haziran ayında Michigan Eyaleti Eğitim Kurulunca, Ortak Çekirdek Eyalet Standartları, "Common Core State Standards (CCSS)" kabul edilmiştir. Bu standartları belirlemenin yanında Matematik ve İngilizce Dil Öğretim Standartları da belirlenmiştir. Eğitim bölgeleri yeni standartlara geçiş yapmaya teşvik edilmiştir (www.michigan.gov/k-12, 2012). Amerika Birleşik Devletlerinde program geliştirme çalışmaları Eyaletlerin Eğitim 
Kurullarınca yapılmakta, yapılan standart çalışmalarını her eğitim bölgesi kendine göre yeniden düzenlemektedir. Belirlenen eğitim standartlarının dışına çıkmadan, yerel veya eyalet düzeyinde yeniden komisyonlar kurulmaktadır. Programların güncellenmesi konusunda yerel çalışmalar teşvik edilmektedir.

İngiliz Dili Öğretim Programını, Michigan Eyaleti Standartlarında kısaca incelediğimizde farklı uygulamalarla karşılaşılmaktadır. Her eğitim bölgesi belirlenmiş olan içeriği kendi bölgelerinin koşullarına göre yeniden ele aldığı ve düzenlediği tespit edilmiştir. Programların uygulanmasına yönelik çok çeşitli eğitim materyali ve araç gereç kullanıldığı gözlemlenmiştir. İlköğretim birinci sınıf öğretmenlerinin hazırlanan programlarının standartlarını öğrencilere kazandırmaları için 13 ciltten oluşan Öğretmen Kılavuz Kitaplarının hazırlandığı belirlenmiştir. Hazırlanan Öğretmen Kılavuz Kitaplarının paralelinde birinci sınıf öğrencilerinin kullanmaları için yaklaşık 300'er sayfalık öğrenci okuma kitapları ve bu kitapların e-kitapları hazırlanmıştır. Programın geliştirilmesi, ders kitapları, öğretmen ve veli kılavuz kitapları aynı komisyon tarafından hazırlandığı tespit edilmiştir. Programlarda okul aile işbirliğine çok önem verildiği tespit edilmiştir. Belirlenen içeriğin sağlıkı bir şekilde uygulanması ve veli desteğinin sağlanması için Veli Kılavuzu hazırlandığı belirlenmiştir. Programların uygulanmasında teknolojik araç gereçler olabildiğince kullanılmaktadır. Teknolojiyi eğitim ortamlarında daha verimli kullanmak için Eğitimde Teknoloji Kullanım Standartları belirlenmiştir. Tüm bu çalışmalar öğrencilere ilk okuma yazma becerisini en verimli bir şekilde kazandırmayı amaçlamaktadır.

\section{Araştırmanın Amacı}

$\mathrm{Bu}$ araştırmada Amerika Birleşik Devletleri, Michigan Eyaletinde ilkokul birinci sınıflarda kullanılan ilk okuma yazma öğretim programda yer alan amaç/kazanımların ve veli kılavuzu incelenerek tanıtılması amaçlanmıştır.

\section{Yöntem}

Bu araştırmada nitel araştırma yöntemlerinden dokuman incelemesi yapılmıştır. Doküman incelemesi, araştırılması hedeflenen olgu veya olaylar hakkında bilgi içeren yazılı dokümanların analizini kapsar (Yıldırım ve Şimşek, 2008). Bu araştırmada dokuman olarak Amerika Birleşik Devletleri, Michigan Eyaletinin üç ayrı eğitim bölgesinde kullanılan ilkokul birinci sınıf ilk okuma yazma öğretim programları ve veli kılavuzları incelenmiştir. 


\section{Verilerin Toplanması ve Analizi}

Araştırmada ilk okuma yazma öğretim programlarına ve veli kılavuzlarına, Michigan eyaletinde yer alan Lansing, East Lansing ve Okemos şehirlerinin Devlet Okulları Eğitim Koordinasyon Merkezlerinin resmi web sayfalarından, bu şehirlerde yer alan resmi ilkokul web sayfalarından ve okul ziyaretleriyle okulların arşivlerinden ulaşılmıştır. İnceleme kapsamına alınan dokümanlar aşağıda belirtilmiştir.

- Lansing, East Lansing ve Okemos Eğitim Koordinatörlüklerinin resmi web sayfalarında yer alan ilk okuma yazma öğretim programlar1,

- Lansing, East Lasning ve Okemos eğitim bölgelerindeki ilkokulların resmi web sitelerinde yer alan ilk okuma yazma öğretim programları ve okullarda kullanılan program kılavuz kitapları ve e-kitaplar,

- Lansing, East Lasning ve Okemos eğitim bölgelerindeki ilkokulların resmi web sitelerinde yer alan ilk okuma yazma öğretim programlarına destek olmaları amacıyla hazırlanmış olan veli kılavuzları incelenmiştir.

Elde edilen dokümanlar sonucunda ilk okuma yazma öğretim programı araştırmanın amacı doğrultusunda iki bölümde ele alınmıştır. Birincisi programın amaç ve kazanımları, diğer bölümde ise programın bileşenleri şeklinde araştırmacılar tarafından belirlenmiştir. Programın bileşenleri içerisinde içerik standartları, öğrenciler için dil becerileri ve aşamaları ve ilk okuma yazma öğretimine yönelik veli kılavuzu ele alınmıştır.

\section{Bulgular}

Bu bölümde Michigan Eyaletine bağll, Lansing, East Lansing ve Okemos Eğitim Bölgelerinde ilk okuma yazma öğretiminde kullanılan programlar ve veli kılavuzlarına yönelik bulgular aşağıda verilmiştir.

\section{Ana Sınıfı Birinci Sınıf ve İkinci Sınıflar İçin İngilizce Dil Sanatları Ortak Temel Devlet Standartları}

Haziran 2010 yılında, Michigan Eyaleti Eğitim Kurulu Matematik ve İngilizce Dil Sanatlarına ilişkin ortak çekirdek dil standartlarını benimsemiştir. İlçeler ve üniversiteler yeni standartlara geçiş yapmaları konusunda teşvik edilmektedir. Bu standartlar doğrultusunda İngilizce öğretiminde ilçeler kendi ihtiyaçları doğrultusunda belirlenmiş olan 
standartları uyarlarken, bu alanlarda öğretmen yetiştiren üniversitelerde yeni standartlara göre öğretmen yetiştirmeleri konusunda teşvik edilmiştir.

Belirlenen standartların ulusal organizasyonlar ve diğer gruplardan gelen bilgi ve belgelerle desteklenmesi öngörülmüştür. Öğretim geliştirme çalışmalarına yerel uzmanların rehberliği doğrultusunda devam edilmesi ve sonuçların sınıflar düzeyinde uygulanması gerektiği belirtilmiştir. Eğitimcilerin yeni standartları nasıl uygulayacakları konusunda eğitilmeleri gerektiği vurgulanmıştır.

Sınıf Düzeyi İçerik Hedefleri ve Ortak Çekirdek Eyalet Standartları arasında bire bir uyumu göstermek gibi bir çabanın olmadığı vurgulanmıştır. Aksine, eklenen dokümanlar Sınıf Düzeyi İçerik Hedefleri temel eğitim programından, öğrenime geçiş için modeller sağlamakta ve Ortak Çekirdek Eyalet Standartları ile değerlendirmeler sıralamaktadır (Michigan State Board of Education, 2010)

\section{Okuma Yazma ve Dil Öğretimi}

Öğrenmeyi geliştirmek için okuma yazma öğretimi ve pratiği, anaokulu ve ilköğretim öğretiminde önemli bir aktivite olarak yer almaktadır. Okuma Yazma ve Dil Öğretimi düşünmeyle direk bağlantılı olan, okuryazarlık, yazılı ifadede yerlilik, akıcı konuşma becerisi, görsel ve işitsel algılama gibi becerilerin öğretimini kapsar. Dil sanatları öğretimindeki bütün içerik konuları birbiriyle bağlantılıdır. İçerik ve metinlerden öğrendiğimiz fikirler, deneyimler ve kültürel bakış açıları, kendi dünya görüşümüzü şekillendirmemize yardımcı olur. Kazandığımız bu anlayış edebi, kültürel ve dil mirasımızı anlamamızı sağlar (Okemosschools, 2012).

\section{İçerik Standartları}

1. Öğrenciler bilgiyi geçmişten gelen bilgilerini hatırlarlar ve tanirlar.

2. Öğrenciler öğrendiklerini anlamlandırabilmek için, değişik taktikleri gözlemlerler, planlarlar ve kullanırlar.

3. Öğrenciler öğrendiklerini anlamlandırırlar.

4. Öğrenciler memnuniyet kazanmak, bilgi edinmek ve görevlerini yerine getirebilmek için iletişim kurarlar.

5. Öğrenciler öğrendiklerini analiz ederler ve değerlendirirler.

\section{Sınıf Öğrencileri İçin Dil Beceriler ve Aşamaları}

Bu bölümde İLKÖĞRETIM birinci sınıf öğrencilerinin dil becerilerini geliştirmeye yönelik kazanımlar ve süreç ayrıntılı olarak verilmiştir. 


\section{a. Okuma}

\section{Kelime Tanıma ve Kelime Çalışmaları}

\section{Ses Farkındalığı}

1. Gerektiğinde sesleri birleştirme ve silme gibi çok çeşitli ses kullanma becerileri ile ses farkındalığı göstermek.

2. Kelimelerin, seslerin birleşmesiyle oluştuğunu ve bir anlam taşıdığını fark etmek.

\section{Sesler}

1. Kelimelerdeki seslerin alfabedeki harfler ile ifade edildiğini anlamak.

2. Tek heceli kelimeleri, birleşimleri ve tek ses oluşturan iki harf yapılarını (Harf-Sesi, ilk hecenin sesi ve kafiye, tüm kelime parçaları, kelime grupları ve th, ch, sh sesleri) anlamak için yapısal ipuçlarını kullanmak

\section{Kelime Tanıma}

1. Sene başından sonuna kadar düzenli olarak artan bir akıcılıkla, metin içinde veya dışında sıklıkla karşılaşılan kelimeleri otomatik olarak tanıma.

2. Üçüncü sınıfta yeterli olabilmek için 220 Dolch basit kelimeleri ve 95 sık kullanılan ismi otomatik olarak tanımada aşama kaydetmek.

3. Bilinmeyen kelimeleri tanımak ve onlara anlam yüklemek amacıyla, ilk harfleri/sesleri, dil kalıplarını, resim ipuçlarını kullanmayı ve alternatif kelime anlamları arasından en iyisini seçmek için içerik ipuçlarını uygulamayı öğrenmek.

4. Birinci sınıf düzeyi metinlerdeki kelimelerin anlamalarına karar vermek için resim ipuçları, kelime birlikleri ve kitap dil yapısı gibi söz dizimsel ve anlamsal ipuçlarını kullanmak.

5. Birinci sınıf düzeyindeki sözlü ve yazılı metinlerdeki sıklıkla karşılaşılan kelimelerin anlamlarını bilmek.

\section{Kelime Haznesi}

Metin ipuçlarl, zihinsel resim ve sorgulama gibi taktikleri ve kaynakları kullanarak nesne, eylem, kavram ve edebi terimler gibi kelimelerin ve kalıpların anlamlarına karar vermek. 


\section{Akıcılık}

1. Metin içinde veya dışında sıklıkla karşılaşılan birinci sınıf düzeyindeki belirli kelimeleri otomatik olarak tanıma ve akıcı okuma.

2. Sesli okuma esnasında noktalama işaretlerini (. ve ?) dikkate alarak tonlamalı, duraklamalı ve vurgulu okuma.

\section{Hikâye}

1. Modern, çok kültürlü ve klasik edebiyata yansitılan ortak mirasımızı ve farklı kültürlerin olduğunu anlamak.

2. Gerçek kurgu, hayal ve halk hikâyelerini içeren öyküsel türün çeşitlerinin amaçlarını ve yapılarını tanımlamak ve anlamak.

3. Problem/çözüm, olay dizileri ve hikâye duygusunu tanımak.

4. Yazarların, hikâye içeriklerini desteklemek için kullandıkları örneklemeler ve hikâyenin duygusunu verebilmek, olay dizisini gösterebilmek amacıyla önce, sonra, şimdi gibi bağlaçları kullandıklarını algılamak.

5. Düşünceyi yansıtmak, bağlantı kurmak, taraf olmak ve anladığını göstermek için kanıt bularak, tartışarak, örnekleyerek ve yazarak tek ve çoklu metinlere cevap vermek.

\section{Bilgilendirici Metin}

1. Basit "Nasıl Yapılır Kitapları", bilim ve sosyal dergiler gibi çeşitli bilgilendirici türlerin yapılarını, özelliklerini ve amaçlarını tanımlamak ve anlamak.

2. Tanımlayıcı ve ardışık tarzdaki bilgilendirici metin özelliklerini tartı̧̧mak.

3. Anahtar ve destekleyici fikirleri anlamayı geliştirmek için yazarların başlıkları, alt başlıkları, etiketli, resimleri ve örneklemeleri nasıl kullandıklarını açıklamak.

4. Düşünceyi yansıtmak, bağlantı kurmak, taraf olmak ve anladığını göstermek için kanıt bularak, tartışarak, örnekleyerek ve yazarak tek ve çoklu metinlere cevap vermek.

\section{Kavrama}

1. Eski bilgileri ve deneyimleri ile metindeki fikirler arasında bağlantı kurarak metin içi ve metinler arası bağlantılar ve karşılaştırmalar yaparak bunları sözlü ve yazılı cevaplarda kullanmak. 
2. Basit sözlü ve yazılı metindeki üç önemli ana fikri ve detayı söyleyebilmek.

3. Okurken soru sorarak, hikâye unsurlarını eşleştirerek ve temel fikir ve detayları sunarak metindeki fikirleri, karakterleri, olayları ve anahtar fikirleri karşılaştırmak.

4. Birinci sınıf düzeyindeki bilimsel, sosyal ve matematiksel metinlerden önemli bilgileri uygulamak.

\section{Üst Biliș}

1. Anlamın ne zaman bozulduğunu anlayarak kendi kendine algılama ve okurken ya da dinlerken algılamayı güçlendirmek için kitap kapağından ve resimlerden önemli tahminler yaparak, bazı düzeltme stratejileri kullanma.

2. Okumadan önce, okuma süresince ve okuduktan sonra soru sorma, metindeki ana temayı ve önemli fikirleri tartışma gibi taktikleri kullanarak kendi kendine metni algilama.

3. Anlamı oluşturmak ve aktarmak ve hangi algılama taktiğinin daha iyi olduğunu tartışmak için becerileri, taktikleri ve aşamaları planlamak, gözlemlemek, düzenlemek ve değerlendirmek.

\section{Önemli Standartlar}

1. Ortak standartları tartı̧̧mak ve geliştirmek, öğretmen rehberliğinde kendisinin ve diğerlerinin yazma doğruluğunu ve kalitesini değerlendirmeye başlama.

\section{Okuma Alışkanlığı}

1. Okuma ve okumayı öğrenme konusunda istekli olma.

2. Evde ve okuldaki boş zamanlarında yeterli düzeyde okuma ve yazma yapma.

b. Yazma

\section{Yazı Türleri}

1. Örneklemeler ve önce, sonra, şimdi, son olarak gibi olay dizisi, hikâye algısı (başlangıç, orta ve bitiş) ve fiziksel tanımlamaları gösteren bağlaçları kullanarak kişisel hikâye yazma.

2. Sınıf düzeyine uygun çok çeşitli şiirleri okumaya dayalı şiir sanati. 
3. Temel fikirleri anlamayı geliştirmek amacıyla, başlık, alt başlık, etiket, fotoğraf ya da örneklemeleri içeren tanımlayıcı, birebir ya da ardışık düzende bir soruya odaklı bilgisel bir parça yazma.

4. Öğretmenin seçtiği bir konu hakkında inceleme soruları yazmak; öğretmenin seçtiği kaynaklardan gerekli bilgiyi tespit etmek ve bilgi toplamaya başlamak; bilgiyi düzenlemek ve bir proje geliştirmek amacıyla yazma becerisini kullanmak.

\section{Yazma Süreci}

1. Hikâye ya da bilgilendirici metin yazarken öğretmen desteğiyle bir amaç belirlemek, dinleyiciyi göz önünde bulundurmak ve edebi dili kullanmak; planlama yaparken yazı tasarımı gibi özel taktikleri kullanmaya başlamak.

2. Bir hikâye ya da bilgilendirici metin yazarken uygun gramer, yapı, teknik ve imla ile birleşik cümle kullanarak önemli fikirleri tasarlamak.

3. Dinleyiciler için metni anlaşılır yapmak amacıyla sesli okuyarak taslağ 1 yeniden incelemek (güçlü fiiller ya da belirli isimler kullanmak ve gerekli bilgiyi eklemek gibi)

4. Prova yapmak; kelime duvarı ve sinıfta hazırlanan kontrol listesi (bireysel ve grup olarak) gibi uygun kaynakları kullanarak yazıyı/resmi düzenlemek.

\section{Kişisel Tarz}

1. Hem hikâye (ana dil, kendine özgü hareket ve duygu) hem de bilgilendirici metindeki (ardışık, özel kelime, görsel sunum) sözlü, yazılı ve görsel mesajları iletmede kişisel tarz oluşturmak.

\section{Gramer ve Yap1}

1. Büyük harfle başlayan nokta, soru işareti ya da ünlem ile biten, bir tam basit cümleyi doğrulukla kullanmak; isim, soyadı ve ben zamirini büyük harfle başlayarak yazmak.

\section{Heceleme}

1. Yazı içeriğinde, yaygın kelime gruplarından sıklıkla karşılaşılan tek heceli kelimeleri doğrulukla hecelemek.

2. Yazı içeriğinde yapısal ipuçlarını (harf/ses, kafiye) ve çevresel kaynakları (kelime duvarları, kelime listeleri) kullanarak az sıklıkla karşılaşılan kelimeleri doğrulukla hecelemek. 


\section{El Yazisı}

1. Küçük ve büyük el yazısı harflerini okunaklı bir şekilde yazabilme.

\section{Yazı Alışkanlığı}

1. Yazma ve yazmayı öğrenmeye istekli olma.

2. Farklı kişilerle iletişimde nezaket ifadeleri, iletişim kurma, sorun çözme, çözüm arama ve rica etme gibi değişik amaçlar için dili inceleme ve kullanma.

3. Hikâye ve bilgilendirici sunumlarda, örnekleme ve fotoğraf gibi destekleyicileri kullanarak uygun mimik, göz teması ve vücut dilini koruyarak etkili biçimde konuşma.

4. Ana dili Amerikan İngilizcesi olan öğrencilerin standart Amerikan İngilizcesinde sunum yapmaları (ana dili İngilizce olmayan öğrenciler kendi düzeylerindeki standart Amerikan İngilizcesiyle sunum yapacaklardır).

5. Kültürel grup üyeliklerinin ve dilin görevi olarak konuşma dilinin hikâye kitaplarından ve sınıf ortamından nasıl farklı olduğunu örnekleyerek göstermek.

\section{c. Konuşma}

1. Konuya odaklı kalarak sürekli sohbetlere katılma, edebi tartışmalarda, karşılıklı sohbetlerde ve diğer iletişimlerde önceki cevaplara dayalı olarak dönüşümlü olarak konuşmak.

2. Uygun mimik, göz kontağı ve destekleyiciler ile problem/çözüm deseni, uygun hikâye yapısı ve ardışık olay dizisini kullanarak bilindik hikâyeleri anlatmak.

3. İfadeyi yansıtarak, anlamlandırarak ve bağlantı kurarak çoklu metin türlerine cevap vermek.

4. Uygun mimik, göz kontağ ve destekleyicileri kullanırken ana fikri vermek amacıyla değişik olayları ve detayları kullanarak bilgisel motif düzeninde sunum planlamak ve sunmak.

\section{d. Dinleme ve Görme}

\section{Uygulamalar}

1. İki basamaklı yönlendirmeleri anlamak, yeniden ifade etmek ve uygulamak. 
2. Sunum ya da bildiri süresince açıklığa kavuşturmak ve anlamak amaciyla uygun soruyu sormak.

3. Küçük ya da büyük gruplar halinde uygun dinleyici davranışları gösterirken bilinçli bir şekilde dinlemek ve izlemek; akran yorumların dinlemek uygun beyan ederek konuya katkıda bulunmak.

4. Mesaj kaynağının karşıdakinin cevabını nasıl etkilediğini anlamak (öğrenci/öğrenci, öğrenci/öğretmen, öğrenci/veli)

5. Farklı ortamlardaki mesajları değerlendirmeye başlamak ve mesaj, gönderici ve alıcı arasındaki ayrımı fark etmek.

\section{Cevaplama}

1. Farklı türleri bilinçli bir şekilde dinleme, izleme ve onlar hakkında bilinçli bir şekilde tartışmak.

2. Kalitesi ve edebi değeri olan klasik ve modern metinleri seçme, dinleme, izleme ve bilinçli bir şekilde dönüt vermek.

3. Tartışarak, örneklendirerek, düşünceyi ifade etmek amacıyla yazarak, anlamlandırarak ve bağlantı kurarak bilinçli bir şekilde dinlenen ya da izlenen çoklu metinlere dönüt verme (Okemosschools, 2012)

\section{3. İlköğretim Birinci Sınıf Öğrencilerine Dil Öğretiminde Veli Kılavuzu}

Birinci Sınıf İngilizce Dil Öğretiminde "English Language Arts (ELA)" sadece okuma ve yazma öğretilmez, okuma yazmandan daha fazla şeyler öğretilir. Bunlar konuşma, dinleme ve görmek gibi becerileri de içerir. İngiliz Dili Öğretimi bize iletişim kurmak için bir yol sunar. İngiliz Dili Öğretimi sayesinde çocuğunuzun okulda ve toplum içinde, evde gerçek sorunları çözmek için ne öğrenirse uygulayabilirsiniz.

Birinci Sınıf sonunda, çocuğunuz aşağıdakileri bilmesi ve yapması gerekir: Kitapçığın arkasında yer alan terimler sözlügünde yer alan kelimeleri çocuğunuzun öğrenmesi beklenir. Bunun yanında okuma, kelime tanıma, ses bilincini ve farkındalığını geliştirmeye yönelik çalışmalar yapmanız gerekir.

Öğrencinizin kelime haznesinin gelişimine yönelik çalışmalar yapılması önerilmektedir. Kelimeleri tanımasına ve anlamlarını öğrenmesine yardımcı olunmalı. Akıcı okumalarına yardımcı olmak için hikâye edici ve bilgilendirici metinlerden faydalanılabilir. Okunan metinleri anlamalarına ve bu metinlerden yola çıarak üst düzey düşünme becerilerinin gelişimine katkı sağlanmalıdır. Okuma ve yazma alışkanlığı 
kazandırılmalıdır. Yazı türleri ve yazma süreciyle ilgili olarak yol gösterici olunmalıdır. Yazım kurallarına uygun olarak kendi kişisel tarzını oluşturmasında yol gösterici olunmalıdır. Harflerin seslerini ve heceleme konusunda doğru yönlendirme yapılmalıdır. El yazısı becerisinin gelişmesi ve el yazısıyla yazmayı kalıcı davranış haline gelmesi konusunda özen gösterilmelidir. Akıcı ve kurallarına uygun bir ses tonuyla konuşmalarında çocuğunuza yardımcı olabilirsiniz. Konuşmada bir söylem geliştirmelerine yardımcı olunmalıdır. Ses tonlamalarına ve vurgularına dikkat edilmelidir. Dinleme ve dinlediği konu hakkında konuşma ve sorulan sorulara makul ve mantıklı yanıtlar vermesine yardımcı olunmalıdır. Kelimelerin ve harflerin kullanımına özen gösterme. İki ünlü veya ünsüz bir arada nasıl kullanıldığına dair örnek verme. İki ünsüz harfi bir araya getirerek tek ses oluşturma. Yazı türlerini ayırt etmelerine, akıcı ve kurallı okumalarına, seslerin stres noktalarını bilerek vurgulu okumalarına, ses bilincinin ve farkındalığının gelişimine katkı sunulmalıdır. Kelimelerdeki ön ek ve son eklerin anlamlarını kavramalarına yardımcı olunması. Sözlü konuşma esnasında konuşmalara ve tartışmalara katılmalarına imkân vermek. Konuşma esansında standart İngilizce kurallarına dikkat etmek. Yazı Türlerini tanımlamak için genellikle şiir, öykü, peri masalları gibi farklı tanımlar kullanılması önerilmektedir (Michigan, K-2_ELA, 2012).

\section{Tartışma, Sonuç ve Öneriler}

Yapılan araştırmada ABD'nin Michigan Eyaletinde halen uygulanmakta olan ilkokul birinci sınıf okuma yazma öğretim, yardımcı kaynaklarıyla birlikte incelenmiştir. Yapılan inceleme doğrultusunda üç temel konu ele alınmıştır. Bunlar programın içeriği, programın kapsamı ve programı destekleyen ek program kaynaklarıdır.

Okuma yazma öğretiminin iyi planlanması eğitim öğretim faaliyetlerinin öğretim yılı içerisinde dağılımını sağlamakta, bu nedenle de zaman ve enerji kaybını önlemektedir (Güneş, 2007). Programın içeriğiyle ilgili yapılan incelemede, kullanılan okuma yazma öğretim programının detaylı olarak hazırlandığı görülmüştür. İlkokul birinci sınıflara yönelik 13 adet kılavuz kitap hazırlandığı belirlenmiştir. Eyalet bazında hazırlanan İngilizce Dil Sanatları öğretim programının çok geniş katılımlı bir ekip çalışması (15 akademisyen yazar, 11 akademik danışman ve 30 uygulayıcı öğretmen) olduğu tespit edilmiştir. Aynı ekibin programların uygulama ders kitaplarını ve e kitapları da yazdıkları belirlenmiştir. Programı 
hazırlayan ekip programın bölgesel uygulanmalara yardımcı olması amacıyla veli ve öğretmen kılavuzları da hazırladıkları tespit edilmiştir.

Elde edilen veriler 1şında, ülkemizde yürütülen öğretim programlarını geliştirme çalışmalarının da geniş katılımlı bir ekip çalışmasıyla yürütülebilir. Türkiye'de etik kabul edilmeyen bir durum olmasına rağmen geniş katılımlı akademisyen ve uygulayıcıların hazırlamış oldukları bir programın ders kitapları, e kitaplar ve yardımcı kaynakların hazırlanmasında da yol gösterici olabilir. İlk okuma yazma öğretimiyle ilgili farklı ülkelerin öğretim programları araştııılması, incelenmesi ve alana katkı sağlayacaktır.

\section{Kisaltmalar}

CCSS: Common Core State Standards / Ortak Çekirdek Eyalet Standartları ELA: English Language Arts and Literacy in History / Social Studies, Science, and Technical Subjects

ELA: İngilizce Dil Sanatları ve Tarih / Sosyal Bilimler, Fen Bilimleri ve Teknik Konular okuryazarlık

CCR: College and Career Readiness / Üniversite ve Kariyer Hazırlığ1

GLCE: Grade Level Content Expectations / Sınıf Düzeyi İçerik Beklentiler

K-2 ELA: Kindergarten - 2nd Grade İngilizce Dil Sanatları / Anasınıf-2. Sınıf İngilizce Dil Sanatları

\section{Kaynakça}

Akyüz, Y. (1999). “17. Yüzyıldan Günümüze Türk Eğitiminde Başlıca Düzenleme ve Geliştirme Çabaları. Milli Eğitim Dergisi, p.144.

Allington, R. L. (2001). What really matters for struggling readers: Designing researchbased programs. New York: Longman.

Ergün, M. (2005). "Cumhuriyet Eğitiminin Genel Değerlendirilmesi" http://www.egitim.aku.edu.tr/ergun4.htm

Günçer, E. \& Kaya, H. (1952). Allfabe Öğretimi ve Alfabe Oyunları. İstanbul: Nadir Kitap.

Güneş, F. (2007). Ses temelli cümle yöntemi ve zihinsel yapılandırma: ses bilinci, yazı bilinci, zihinsel sözlük, beyin teknolojisi, anlama modelleri. Ankara: Nobel Yayın.

Jasinowski, J., Eisen, P., \& Kleinert, R. (2005). 2005 Skills gap report - A survey of the American manufacturing workforce. Retrieved July 17, 2006.

MEB. (1924). 1924 İlkmektep Öğretim Programı. Ankara: Yayımlar Dairesi Arşiv Kütüphanesi. 
MEB. (1926). 1926 İlkmektep Öğretim Programı. Ankara: Yayımlar Dairesi Arşiv Kütüphanesi.

MEB. (1930). 1930 İlkmektep Öğretim Programı. İstanbul: Devlet Matbaası.

MEB. (1936). 1936 İlkmektep Öğretim Programı. İstanbul: Devlet Matbaası.

MEB. (1948). 1948 İlkokul Öğretim Programı. İstanbul: Devlet Matbaası.

MEB. (1968). 1968 İlkokul Öğretim Programı. İstanbul: Milli Eğitim Basımevi.

MEB. (1981a). 26.10.1981 Tarih ve 2098 Sayılı Tebliğler Dergisi. İstanbul: Milli Eğitim Basımevi.

MEB. (1981b). 1981 İlköğretim Kurumları Türkçe Eğitimi Programı. İstanbul: Milli Eğitim Basımevi.

MEB. (2005a). MEB Öğretim Geliştirme Süreci. 10 Nisan 2012 tarihinde, http://programlar.meb.gov.tr/index/baskan.htm, adresinden erişildi.

MEB. (2005b). “Milli Eğitimi Geliştirme Projesi." 10 Nisan 2012 tarihinde, http://earged.meb.gov.tr/mlo/ana.htm, adresinden erişildi.

MEB. (2005c). "Yeni Programların Geliştirilmesi." 10 Nisan 2012 tarihinde, http://ttkb.meb.gov.tr/ogretmen, adresinden erişildi.

MEB. (2005d). İlköğretim 1-5. Sınıf Programları Tanıtım El Kitabı. Ankara: Devlet Kitapları Müdürlüğü Basım Evi.

Michigan Department of Education. (2010). English Language Arts. Common Core State Standards K-12: 10 Nisan 2012 tarihinde, www.michigan.gov/k-12, adresinden erişildi.

Michigan Department of Education. (2010). English Language Arts. Common Core State Standards K-2: 10 Nisan 2012 tarihinde, http://www.michigan.gov/documents/mde/K-2_ELA_357700_7.pdf. adresinden erşildi.

Michigan State Board of Education. (2010). Kindergarten - Second Grade English Language Art: Michigan Department of Education: 12 Nisan 2012 tarihinde, http://www.michigan.gov/documents/mde/K2_ELA_357700_7.pdf adresinden erişildi.

National Center on Education and the Economy (2007). Tough choices or tough times: The report of the New Commission on the Skills of the American Workforce. Washington, DC: Author.

Okemos Public Schools, (2012). Curriculum-Language Arts. 10 Nisan 2012 tarihinde, http://www.okemosschools.net/education/components/scrapbook/d efault.php?sectiondetailid $=5450 \&$. adresinden erişildi.

Yıldırım, A.; H., Şimşek. (2008). Sosyal Bilimlerde Nitel Araştırma Yöntemleri. Ankara: Seçkin Yayınları. 